Zeszyty Naukowe Szkoły Głównej Gospodarstwa Wiejskiego w Warszawie Problemy Rolnictwa Światowego tom 17 (XXXII), zeszyt 3, 2017: 7-16

DOI: $10.22630 /$ PRS.2017.17.3.48

Maryla Bieniek-Majka1, Anna Matuszczak $^{2}$

Uniwersytet Ekonomiczny w Poznaniu

\title{
Rentowność kujawsko-pomorskich grup i organizacji producentów owoców i warzyw
}

\section{Profitability of Kuyavian-Pomeranian Fruit and Vegetable Producers and Organizations}

\begin{abstract}
Synopsis. Celem artykułu było ukazanie relacji pomiędzy czynnikami kształtującymi rentowność kapitałów własnych grup i organizacji producentów owoców i warzyw za pomocą modelu Du Ponta Analizy dokonano na podstawie danych ze sprawozdań finansowych w/w podmiotów funkcjonujących na terenie województwa kujawsko-pomorskiego w latach 2005-2014. Uzyskane wyniki wskazały na zmniejszającą się rentowność funkcjonujących jednostek, która wynikła z wysokich kosztów obsługi kapitału obcego, zmniejszonej zyskowności sprzedaży a także mniejszej rotacji posiadanych aktywów. Czynniki te powodowały iż mieliśmy do czynienia z ujemnym działaniem dźwigni finansowej. Mimo niesprzyjających czynników wartość średniego wskaźnika zwrotu z kapitału własnego w całym badanym okresie była dodatnia. Pozwala to sądzić, że przy odpowiednim zarządzaniu finansami grupy i organizacje producentów owoców i warzyw będą w przyszłości miały możliwość generować środki, które spowodują utrzymanie, a nawet rozwój koncentracji podaży na tym rynku. Zwiększenie zyskowności tych jednostek będzie miało przełożenie na zaspokojenie oczekiwań ich członków.
\end{abstract}

Słowa kluczowe: rentowność, konkurencyjność, grupy i organizacje producentów owoców i warzyw

\begin{abstract}
The aim of the article was to present the relationship between the factors influencing the profitability of fruit and vegetable producers and organizations using the Du Pont model. Analysis was conducted on data from the financial statements of the aforementioned entities operating in the territory of the Kuyavian-Pomeranian voivodeship in the years 2005-2014. The results show a declining viability of existing units, which results from the high cost of servicing foreign capital, reduced profitability and reduced turnover of assets. These factors have resulted in negative financial leverage. However, despite unfavorable factors, the average return on equity over the period considered was positive. This allows for the possibility that, with sound financial management, producers and organizations of fruit and vegetable growers will in future have the opportunity to generate resources that will sustain and even develop a concentrated supply in this market. Increasing profitability of these units will also help satisfy the expectations of their members.
\end{abstract}

Key words: profitability, competitiveness, fruit and vegetables producers and organizations, Poland

\section{Wprowadzenie}

Proces integracji na rynku owoców i warzyw w obecnej postaci rozpoczął się Polsce po akcesji do Unii Europejskiej. W celu zniwelowania istniejących różnic pomiędzy krajami tak zwanej „starej Unii”, a krajami wstępującymi uruchomiono w ramach Wspólnej Polityki

\footnotetext{
${ }^{1}$ dr, Katedra Makroekonomii i Gospodarki Żywnościowej UE w Poznaniu, Al. Niepodległości 10, 61-875 Poznań, e-mail: maryl.b@wp.pl

2 dr hab., prof. UEP, Katedra Makroekonomii i Gospodarki Żywnościowej UE w Poznaniu,

Al. Niepodległości 10,61-875 Poznań, e-mail: anna.matuszczak@ue.poznan.pl
} 
Rolnej mechanizm wsparcia dla konsolidujących się producentów owoców i warzyw³ Głównym celem działania było zwiększenie konkurencyjności zintegrowanych producentów owoców i warzyw oraz organizacja tego rynku dająca możliwość zwiększenia opłacalności produkcji wynikającej między innymi z efektów jej skali.

Grupy i organizacje producentów owoców i warzyw w Polsce powstawały do 2012 roku, chociaż z różną intensywnością. Zaprzestanie koncentracji producentów wynikało ze zmiany legislacji ograniczającej finansowe wsparcie (Bieniek-Majka, 2014, s. 88). Mimo, iż nie powstają już nowe grupy producentów owoców i warzyw to efektywność funkcjonowania obecnych budzi szerokie zainteresowanie. Celem artykułu było ukazanie relacji pomiędzy czynnikami kształtującymi rentowność kapitałów własnych grup i organizacji producentów owoców i warzyw za pomocą modelu Du Ponta. Jak zauważają Wasilewski i Gałecka, rentowność najdokładniej odzwierciedla efektywność gospodarowania $\mathrm{w}$ przedsiębiorstwach. Do oceny przedsiębiorstw oraz zdolności kierownictwa do generowania zysku z zaangażowanych $\mathrm{w}$ działalność środków służą wskaźniki rentowności określane także, jako wskaźniki zyskowności lub stopy zwrotu. Rentowność oznacza osiąganie nadwyżki przychodów ze sprzedaży nad kosztami ich uzyskania, miarą natomiast rentowności jest relacja osiąganych zysków do zaangażowanych kapitałów lub do efektów zastosowanych czynników produkcji (Wasilewski, Gałecka, 2010, s. 231).

\section{Dane i metody}

W celu wskazania czynników kształtujących rentowność kapitału własnego kujawskopomorskich grup i organizacji producentów owoców i warzyw został wykorzystany powszechnie znany model Du Ponta, który jest najbardziej rozpowszechnioną piramidalną formą rozbudowy wskaźnika rentowności. Badaniem zostały objęte wszystkie jednostki ${ }^{4}$, które funkcjonowały w województwie kujawsko-pomorskim w latach 2005-2014. Dane źródłowe do przeprowadzenia analiz pochodziły ze sprawozdań finansowych grup i organizacji producentów owoców i warzyw. Do analizy i oceny rentowności przedsiębiorstw przedstawionej za pomocą modelu Du Ponta wykorzystano najbardziej syntetyczny wskaźnik, to jest stopę zwrotu z kapitału własnego ROE, który jest iloczynem dwóch wielkości: wskaźnika rentowności majątku ogółem ROA oraz tak zwanego mnożnika kapitału własnego. Dalsze rozwiniecie równania wskazuje, że na rentowność kapitału własnego mają wpływ także rentowność sprzedaży ROS i rotacji aktywów (CzerwińskaKayzer, 2006, s. 82). Jak zauważają Bieniasz, Czerwińska-Kayzer, Gołaś (2008, s. 54-55) model Du Ponta w oryginalnej wersji był reprezentowany w formie równania:

Zysk netto/sprzedaż(ROS)x sprzedaż/aktywa ogółem (produktywność aktywów ogólem $)=$ zysk netto/aktywa ogólem $=$ ROA.

\footnotetext{
${ }^{3}$ Program wsparcia był skierowany do nowopowstałych grup (wstępnie uznanych), które to w ciągu maksymalnie 5 lat miały zrealizować plan dochodzenia do uznania. Po tym okresie mogły otrzymać status uznanej organizacji.

${ }^{4}$ Liczebność próby badawczej wynosiła 40 grup i organizacji producentów owoców i warzyw zlokalizowanych w województwie kujawsko-pomorskim, z czego 80\% funkcjonowało jako spółki z ograniczona odpowiedzialnością, $15 \%$ jako stowarzyszenia i 5\% jako spółdzielnie. Status organizacji producentów miało $68 \%$ badanych jednostek. Wstępnie uznane grupy funkcjonowały tylko w formie spółki z ograniczoną odpowiedzialnością.
} 
W późniejszym czasie oryginalny model Du Ponta został wzbogacony o mnożnik kapitału i po zmodyfikowaniu model przedstawia się następująco:

\section{Zysk netto/sprzedaż $x$ sprzedaż/aktywa ogółem $x$ aktywa ogółem/kapitał własny=ROE}

Wiążąc oba równania otrzymano model, w którym analizie można poddać trzy główne czynniki wpływające na rentowność kapitału własnego: zysk zawarty w każdej złotówce przychodu ze sprzedaży, rotację aktywów oraz wielkość kapitałów własnych skierowanych na finansowanie aktywów firmy, czyli dźwignię kapitałową.

\section{Wyniki badań}

Możliwość wykorzystania modelu Du Ponta do oceny kondycji finansowej przedsiębiorstw i wskazania czynników ją kształtujących jest przesłanką do przedstawienia i oceny rentowności kujawsko-pomorskich grup i organizacji producentów owoców i warzyw. Uzyskane, zagregowane dane zaprezentowano za pomocą schematu 1.

\begin{tabular}{|c|r|}
\hline Rok & \multicolumn{2}{|c|}{ ROS } \\
\hline 2005 & 0,03 \\
\hline 2006 & 0,02 \\
\hline 2007 & 0 \\
\hline 2008 & 0,06 \\
\hline 2009 & $-0,02$ \\
\hline 2010 & 0,01 \\
\hline 2011 & $-0,08$ \\
\hline 2012 & $-0,13$ \\
\hline 2013 & $-0,09$ \\
\hline 2014 & $-0,07$ \\
\hline
\end{tabular}

\begin{tabular}{|c|r|}
\hline Rok & $\begin{array}{c}\text { Wskaźnik obrotu } \\
\text { aktywów }\end{array}$ \\
\hline 2005 & 2 \\
\hline 2006 & 0,95 \\
\hline 2007 & 1 \\
\hline 2008 & 0,3 \\
\hline 2009 & $-0,8$ \\
\hline 2010 & 1 \\
\hline 2011 & 1,21 \\
\hline 2012 & 0,27 \\
\hline 2013 & 0,13 \\
\hline 2014 & 0,43 \\
\hline
\end{tabular}

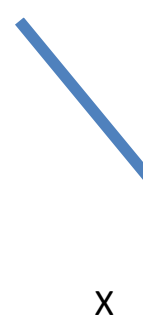

\begin{tabular}{|c|r|}
\hline Rok & \multicolumn{1}{|c|}{ ROA } \\
\hline 2005 & 0,06 \\
\hline 2006 & 0,019 \\
\hline 2007 & $-0,48$ \\
\hline 2008 & 0,018 \\
\hline 2009 & 0,016 \\
\hline 2010 & 0,01 \\
\hline 2011 & $-0,097$ \\
\hline 2012 & $-0,035$ \\
\hline 2013 & $-0,012$ \\
\hline 2014 & $-0,03$ \\
\hline
\end{tabular}

\begin{tabular}{|c|c|c|}
\hline \multirow{11}{*}{$X$} & Rok & $\mathrm{ROE}$ \\
\hline & 2005 & 0,77 \\
\hline & 2006 & 0,15 \\
\hline & 2007 & 0,71 \\
\hline & 2008 & 0,05 \\
\hline & 2009 & 0,21 \\
\hline & 2010 & 1,37 \\
\hline & 2011 & 0,35 \\
\hline & 2012 & 0,23 \\
\hline & 2013 & 0,37 \\
\hline & 2014 & 0,31 \\
\hline
\end{tabular}

\begin{tabular}{|c|r|}
\hline Rok & $\begin{array}{c}\text { Mnożnik kapitału } \\
\text { własnego }\end{array}$ \\
\hline 2005 & 12,83 \\
\hline 2006 & 8,09 \\
\hline 2007 & $-1,48$ \\
\hline 2008 & 2,76 \\
\hline 2009 & 13,07 \\
\hline 2010 & $-137,00$ \\
\hline 2011 & $-3,60$ \\
\hline 2012 & $-6,56$ \\
\hline 2013 & $-30,90$ \\
\hline 2014 & $-10,33$ \\
\hline
\end{tabular}

Schemat 1. Model analizy Du Ponta dla kujawsko-pomorskich grup i organizacji producentów owoców i warzyw Scheme 1. Du Pont analysis model for Kuyavian-Pomeranian fruit and vegetable producers Źródło: opracowanie własne. 


\section{M. Bieniek-Majka, A. Matuszczak}

Analizę modelu należy rozpocząć od sprawdzenia rentowności przychodów, która to jest wynikiem podstawowej działalności każdego przedsiębiorstwa i ma wpływ na kreowanie pozostałych wielkości.

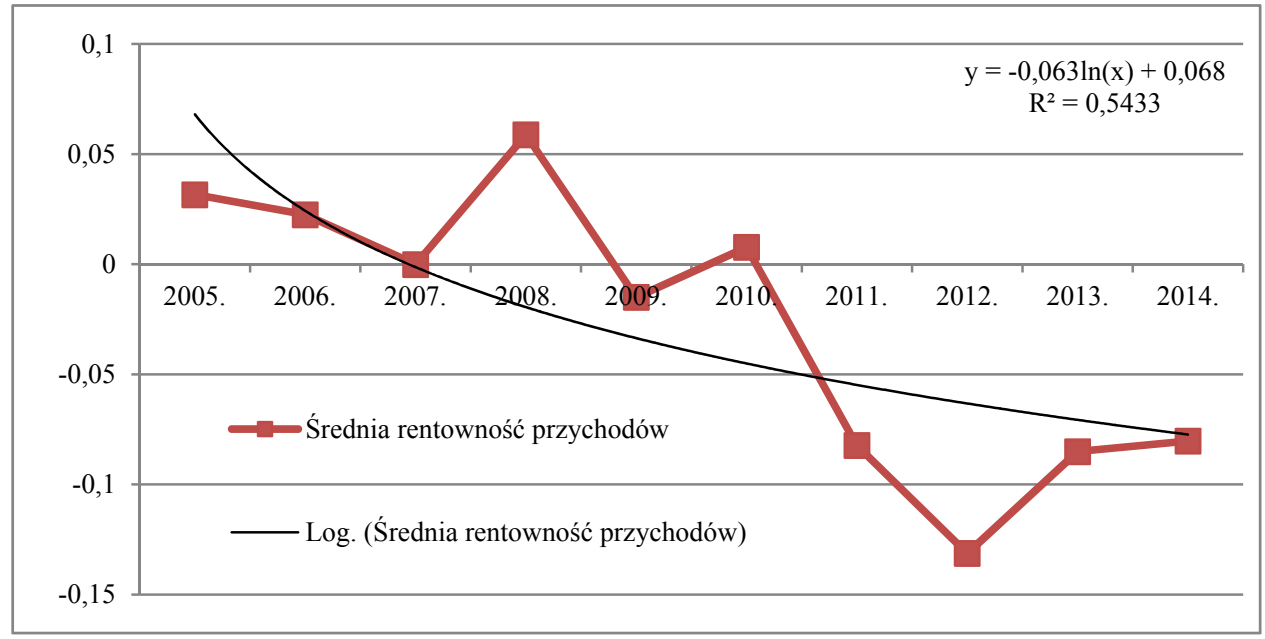

Rys. 1. Średnia rentowność sprzedaży kujawsko pomorskich grup i organizacji producentów owoców i warzyw w latach 2005-2014

Fig. 1. Average profitability of Kuyavian-Pomeranian fruit and vegetable producer and organizations in 2005-2014

Źródło: opracowanie własne.

Analizując rentowność sprzedaży wszystkich grup i organizacji producentów, w całym badanym okresie zauważyć można, że średnio od 2009 roku były one nierentowne (rys. 1). $\mathrm{Na}$ wzrost rentowności w 2010 roku miał wpływ wzrost cen owoców i warzyw spowodowany ograniczeniem podaży wynikającym z warunków agrometeorologicznych (powódź, przymrozki).

Tabela 1.Wskaźnik rentowności sprzedaży grup i organizacji producentów owoców i warzyw w województwie kujawsko-pomorskim w latach 2005-2014

Table 1. Profitability of fruit and vegetable producers and organizations in Kuyavian-Pomeranian voivodship in 2005-2014

\begin{tabular}{l|cc}
\hline \multicolumn{1}{c|}{ Wyszczególnienie } & ROS & $\begin{array}{c}\text { ROS } \\
\text { w 2014 r. }\end{array}$ \\
\hline $\begin{array}{l}\text { Uznane organizacje producentów } \\
\text { owoców i warzyw }\end{array}$ & $-0,045$ & $-0,1055$ \\
$\begin{array}{l}\text { Wstępnie uznane grupy } \\
\text { producentów owoców i warzyw }\end{array}$ & $-0,121$ & $-0,065$ \\
$\begin{array}{l}\text { Razem grupy i organizacje } \\
\text { producentów owoców i warzyw }\end{array}$ & $-0,061$ & $-0,075$ \\
\hline
\end{tabular}

Źródło: opracowanie własne. 
Analizując średnią rentowność sprzedaży w zależności od statusu jaki posiadała badana grupa można stwierdzić, że w przypadku uznanych organizacji producenckich średnia rentowność $\mathrm{w}$ badanym okresie była na poziomie $-0,045$, a wstępnie uznanych grup na poziomie -0,121 (tabl. 1). W 2014 roku rentowność uznanych organizacji w stosunku do średniej zmalała, a wstępnie uznanych grup wzrosła osiągając poziom -0,065 w przypadku organizacji i $-0,1055 \mathrm{w}$ przypadku wstępnie uznanych grup.

$\mathrm{Z}$ równania w modelu Du Ponta wynika, że określony poziom wskaźnika rentowności aktywów ROA osiągnąć można za pomocą wyboru różnych kombinacji rentowności sprzedaży ROS i rotacji aktywów. W przypadku analizowanych przedsiębiorstw konsolidujących producentów owoców i warzyw widać, że w badanym okresie nie tylko rentowność przychodów miała tendencję malejącą, ale także i zmniejszenie produktywności uzyskanych aktywów. Podobiński ${ }^{5}$ zauważa, że praktyka gospodarcza dowodzi iż „uzyskanie proporcjonalnego wzrostu wartości obu czynników jest trudne do osiągnięcia. Dlatego wyższy poziom rentowności sprzedaży może być osiągnięty dzięki poprawie wielkości drugiego czynnika, czyli przyspieszenia obrotu aktywów. Można wówczas posłużyć się jedną z następujących reguł: „mały obrót - duży zysk” - polega ona na zwiększeniu marży zysku na sprzedaży, czyli małym obrocie związanym z wysoką ceną towaru, lub „duży obrót - mały zysk" - przy której następuje obniżenie marży zysku na sprzedaży i przyspieszenie rotacji. Obniżenie ceny sprzedaży skutkuje zwiększonym obrotem". W przypadku producentów owoców i warzyw zastosowanie pierwszej reguły wydaje się nierealnym, a druga, pozwalająca na zwiększenie obrotu jest jednym z podstawowych celów koncentracji na rynku. Właściwym wydawałoby się zwiększanie aktywów obrotowych, natomiast w badanych jednostkach co prawda zanotowano ich wzrost, jednakże udział aktywów obrotowych w aktywach ogółem zmniejszał się ${ }^{6}$. Skutkiem takiego działania było zmniejszenie rotacji aktywów.

Biorąc pod uwagę fakt dążenia jednostek do maksymalizacji rentowności zainwestowanego kapitału własnego Podobiński dalej doradza, iż „wzrost rentowności kapitału własnego ROE można uzyskać poprzez zmianę struktury finansowania, tzn. zwiększając udział kapitałów obcych w finansowaniu majątku, co określane jest mianem tzw. dźwigni finansowej. Efekt finansowania obcego będzie pozytywny, jeśli ROE $>$ ROA. Tak długo, dopóki występuje wzrost wskaźnika ROE w związku ze wzrostem zadłużenia, mamy do czynienia z dodatnim efektem dźwigni finansowej. Jeżeli jednak wzrost zadłużenia powoduje spadek wskaźnika ROE, to występuje ujemna dźwignia finansowa”. I właśnie taką sytuację mogliśmy zaobserwować w przypadku badanych grup i organizacji producentów owoców i warzyw. Wydaje się, że odsetki płacone z tytułu zaangażowania kapitału obcego pomniejszające wynik finansowy osiągnęły taki poziom, że efekty wynikające z zaabsorbowania kapitału obcego były niższe od kosztów jego obsługi. Świadczy to także o nadmiernym zaangażowaniu kapitału obcego (rys.2) w pozyskanie przede wszystkim aktywów trwałych, który wynikał z możliwości jego pozyskania w ramach mechanizmu wsparcia dla tego sektora z programu Wspólnej Polityki Rolnej, a także pokrycia pozostałej części środkami uzyskanymi z kredytu.

\footnotetext{
${ }^{5}$ http://ksiegowosc.infor.pl/abc/53030,Jak-poglebic-analize-rentownosci-firmy-model-DuPonta.html?action=ad\&adid=622440 - data dostępu 10.05.2017

${ }^{6}$ Średni poziom aktywów trwałych w badanym okresie wzrastał i średnio w 2014 roku wyniósł 82\%, zanotowano wiele przypadków, w których poziomo ten był ponad $90 \%$
} 


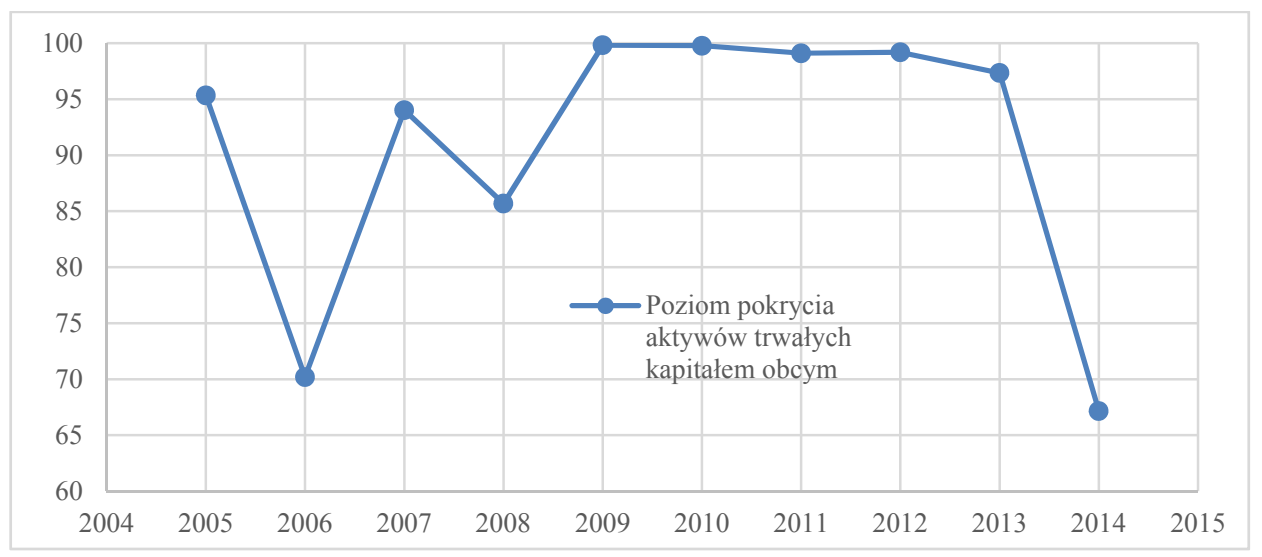

Rys. 2. Średni poziom pokrycia aktywów trwałych kapitałem obcym kujawsko-pomorskich grup i organizacji producentów owoców i warzyw w latach 2005-2014

Fig. 2. Average level of coverage of fixed assets with foreign capital of Kuyavian-Pomeranian fruit and vegetable producers and organizations in 2005-2014

Źródło: opracowanie własne.

Pamiętając, że dofinansowanie do kwalifikowanych kosztów inwestycji można było uzyskać na mocy przepisów z 2007 roku, a następnie te środki w 2011 i w 2012 roku ograniczono to można zauważyć (rys. 3) korelację pomiędzy wspomnianą legislacją, a rentownością aktywów.

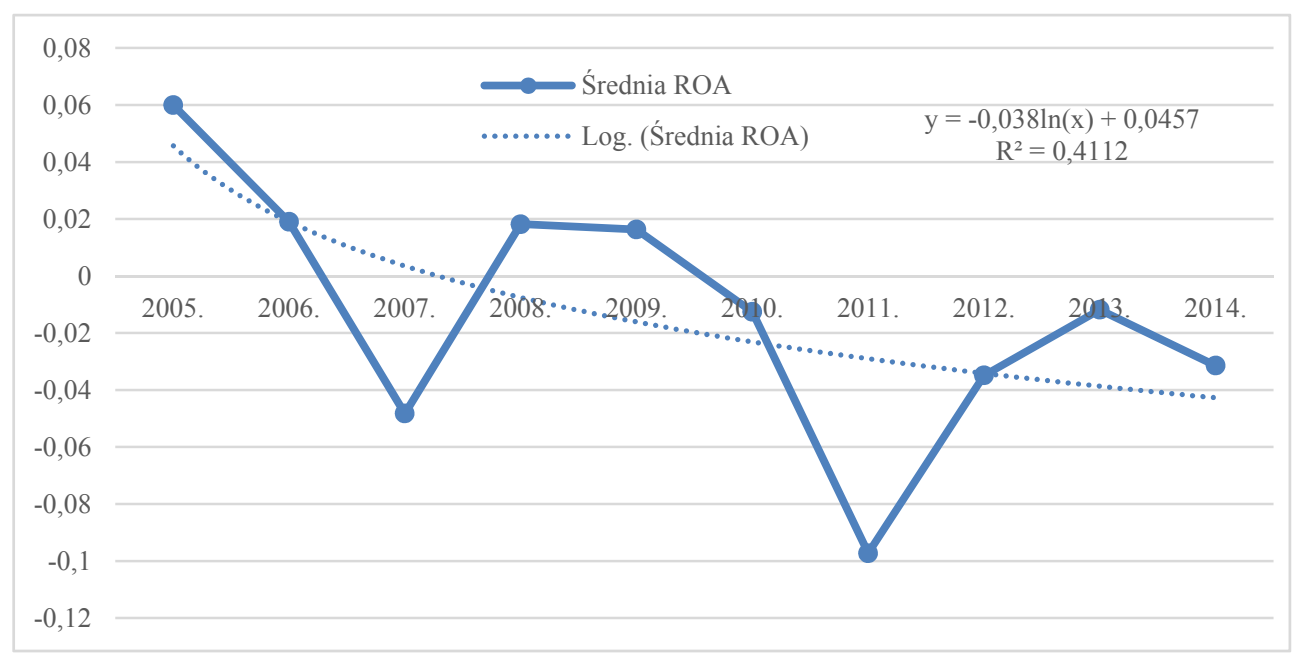

Rys. 3. Średni wskaźnik rentowności aktywów kujawsko-pomorskie grupy i organizacje producentów owoców i warzyw w latach 2005-2014

Fig. 3. Average return on assets of Kuyavian-Pomeranian fruit and vegetable producers and organizations in 2005-2014

Źródło: opracowanie własne 
Teoretycznie wysoki poziom aktywów trwałych wskazuje na brak elastyczności jednostek i ryzyko nieprzystosowania do zmieniających się warunków rynkowych, gdyż majątek ten wytwarza wysokie koszty oraz posiada niską zdolność do generowania zysków. Biorąc po uwagę wielkość zaabsorbowanych środków z programu pomocowego i przeznaczenie ich na inwestycje powiększające aktywa, szczególnie jak wcześniej wspomniano aktywa trwałe, to zanotowany $\mathrm{w}$ analizowanych podmiotach spadek rentowności aktywów (średni wskaźnik ROA na poziomie - 0,029, który minimalnie uległ obniżeniu w 2014 roku)potwierdza, że uzyskano ich nadmierną ilość, czyli dokonano przeinwestowania.

Tabela 2. Wskaźnik rentowności aktywów w kujawsko-pomorskich grup i organizacji producentów owoców i warzyw w zależności od formy prawnej i uzyskanego statusu w latach 2005-2014

Table 2. Profitability rate of assets in Kuyavian-Pomeranian fruit and vegetable producers and organizations depending on the legal form and status obtained in 2005-2014

\begin{tabular}{|c|c|c|}
\hline Forma prawna & ROA & $\begin{array}{c}\text { ROA } \\
\text { w } 2014 \text { roku }\end{array}$ \\
\hline stowarzyszenia & $-0,087$ & $-0,023$ \\
\hline spółdzielnie & 0,048 & $-0,064$ \\
\hline spółki z ograniczoną odpowiedzialnością & $-0,028$ & $-0,017$ \\
\hline \multicolumn{3}{|l|}{ w tym } \\
\hline wstepnie uznane grupy & $-0,046$ & $-0,005$ \\
\hline uznane organizacje & $-0,024$ & $-0,025$ \\
\hline Razem grupy i organizacje producentów owoców i warzyw & $-0,029$ & $-0,031$ \\
\hline
\end{tabular}

Źródło: opracowanie własne.

Na podstawie danych zawartych w tabeli 2. można zauważyć, że organizacje, które dłużej funkcjonują na rynku mają niemal o połowę niższy wskaźnik. Średnia rentowność w badanym okresie była dodatnia tylko w jednostkach funkcjonujących jako spółdzielnie. Mimo iż w ostatnim, 2014 roku, ich wskaźnik rentowności aktywów był ujemny, to w całym badanym okresie wyniósł 0,048.Zadawalający jest fakt, że efektywność aktywów wstępnie uznanych grup producentów owoców i warzyw wykazuje tendencję wzrostową. Mimo iż średnia dla analizowanego okresu, wśród badanych wstępnie uznanych grup wynosi $-0,05$, to w 2014 roku wyniosła już - 0,005 , a $42 \%$ spółek osiągnęło rentowność ze swoich aktywów. Niepokojąca natomiast jest utrzymująca się średnia rentowność spółek w badanych latach wśród uznanych organizacji na poziomie ROA $=-0,024$, i zanotowany „ujemny” poziom ROA w 2014 roku w przypadku $80 \%$ z nich.

Z przedstawionych powyżej wartości wskaźników elementów kształtujących rentowność kapitałów własnych można wywnioskować, że finansowane z kapitału obcego inwestycje produkcyjne spowodowały wzrost wartości aktywów, a relatywny spadek udziału kapitałów własnych spowodował na początku badanego okresu zanotowanie dodatniego efektu mnożnika. Jednakże w dalszym czasie opóźniający się przyrost sprzedaży w stosunku do przyrostu aktywów wpłynął na niego negatywnie. Mniej efektywna sprzedaż, przy

\footnotetext{
${ }^{7}$ do 2014 roku kujawsko-pomorskie grupy i organizacje producentów owoców i warzyw zaabsorbowały 0,94 mld zł, (14\% środków skierowanych na ten cel do Polski) które zostały przeznaczone na pokrycie $75 \%$ kwalifikowalnych kosztów inwestycji - (Bieniek-Majka 2016, s. 228)
} 


\section{M. Bieniek-Majka, A. Matuszczak}

rosnących kosztach (m.in. amortyzacji, czy odsetek od kapitału obcego) spowodowała obniżenie rentowności netto.

Uzyskując przychody, a nie generując zysku netto badane jednostki udowodniły wysoki poziom kosztów. Niski udziału kapitałów własnych przy rozpoczęciu procesu inwestycyjnego spowodował konsekwencję w konieczności spłaty zobowiązań. Producenci owoców i warzyw tworząc grupę producentów zainwestowali, co prawda w niewielkim stopniu, kapitał własny, jednakże oczekiwali zwrotu z poczynionych inwestycji. I tak w badanym okresie średni zwrot $\mathrm{z}$ kapitału własnego we wszystkich jednostkach uplasował się na poziomie 0,416 .

Tabela 3. Wskaźnik rentowności kapitałów własnych kujawsko-pomorskich grup i organizacji producentów owoców i warzyw w zależności od formy prawnej i uzyskanego statusu w latach 2005-2014

Table 3. Return on equity in Kuyavian-Pomeranian fruit and vegetable producers and organizations depending on the legal form and status obtained in 2005-2014

\begin{tabular}{|c|c|c|}
\hline Forma prawna & ROE & $\begin{array}{c}\text { ROE } \\
\text { w } 2014 \text { roku }\end{array}$ \\
\hline stowarzyszenia & 0,122 & $-0,310$ \\
\hline spółdzielnie & 0,211 & $-0,140$ \\
\hline spółki z ograniczoną odpowiedzialnością & 0,456 & 0,367 \\
\hline \multicolumn{3}{|l|}{ w tym } \\
\hline wstępnie uznane grupy & 0,357 & $-0,308$ \\
\hline uznane organizacje & 0,504 & 0,794 \\
\hline Razem grupy i organizacje producentów owoców i warzyw & 0,416 & 0,308 \\
\hline
\end{tabular}

Źródło: opracowanie własne.

Analizując kształtowanie się wskaźnika rentowności kapitału własnego uwzględniając status podmiotów zauważono, iż w przypadku uznanych organizacji widać wzrost średniego poziomu zwrotu z kapitałów własnych w 2014 roku do poziomu 0,706 (-0,14 oraz $-0,31$ w przypadku spółdzielni i stowarzyszeń oraz 0,794 w przypadku spółek z ograniczona odpowiedzialnością). Wstępnie uznane grupy w badanym okresie uzyskały średni zwrot z wniesionych kapitałów własnych na poziomie 0,357. W 2014 roku średnia zwrotu z kapitału własnego była ujemna $(-0,308)$ na co wpływ miał brak rentowności $17 \%$ spółek.

Jednakże należy zwrócić uwagę na różnicę tendencji rentowności kapitałów własnych w stosunku do rentowności aktywów w zależności od formy prawnej. Przypominając, że rentowne aktywa zanotowano w spółdzielniach (tab. 2), to wyższą rentownościa zaangażowanych kapitałów własnych charakteryzowały się grupy i organizacje producentów funkcjonujące w formie spółki z ograniczoną odpowiedzialnością (tab. 3). 


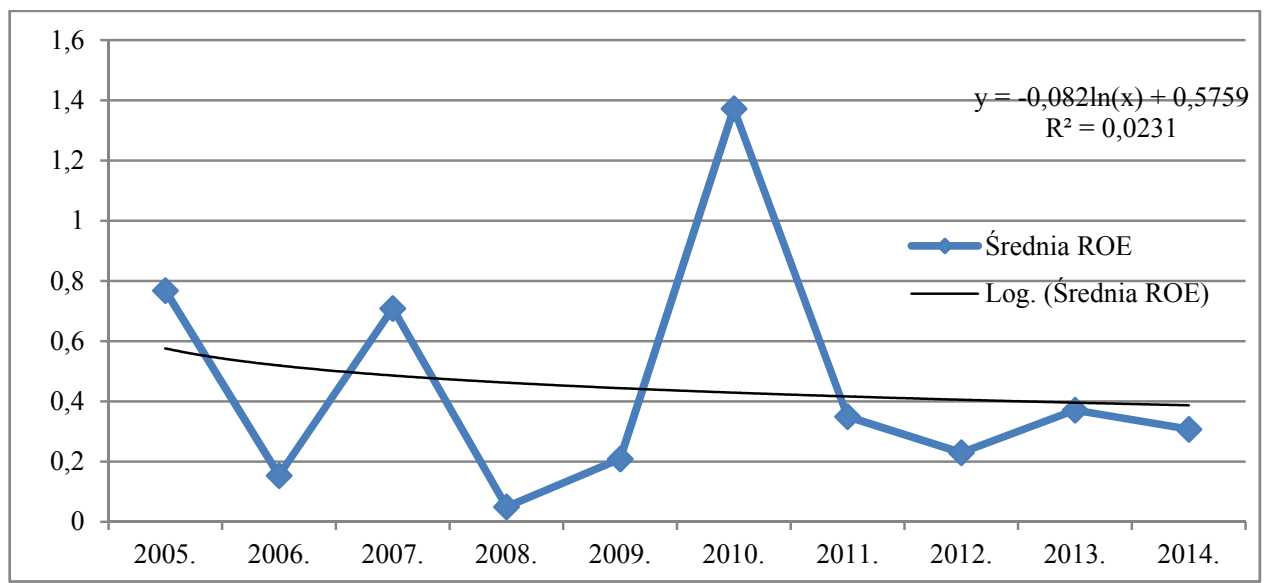

Rys. 4. Średnia rentowność kapitałów własnych kujawsko pomorskich grup i organizacji producentów owoców i warzyw w latach 2005-2014

Fig. 4. Average return on equity of Kuyavian-Pomeranian fruit and vegetables producers and organizations in 2005-2014

Źródło: opracowanie własne.

Mimo braku rentowności w niektórych przypadkach należy zauważyć, że przeciętnie rentowność kapitału własnego w badanym okresie była zawsze dodatnia (rys. 4). Świadczy to o efektywności zaangażowanego kapitału i może prowadzić do uzyskania możliwości rozwojowych przedsiębiorstwa (Skowronek-Mielczarek, Leszczyński, 2008, s. 195).Średni wskaźnik rentowności kapitału własnego w badanym okresie wyróżniał się dużą fluktuacją i charakteryzował się tendencją malejącą. Utrzymanie się tej skłonności może w przyszłości zniechęcić do inwestowania $\mathrm{w}$ tę formę działalności, bądź w skrajnych przypadkach spowodować wycofanie się obecnych członków.

\section{Podsumowanie}

Z syntetycznie zaprezentowanego modelu Du Ponta wynika, że rentowność kapitału własnego zależy od rentowności kapitału całkowitego i struktury kapitału. Właściwe zarzadzanie strukturą zadłużenia w przedsiębiorstwach wpływa na wielkość osiąganego zwrotu z kapitału własnego. Z kolei rentowność kapitału całkowitego zależy od rentowności obrotu oraz produktywności aktywów. Chcąc uzyskać większą różnicę pomiędzy przychodami i kosztami należy umiejętnie nimi zarządzać z jednej strony, ale też należy też zwrócić uwagę na wielkość posiadanego majątku, jego strukturę i zmiany w czasie. Wzrost rentowności kapitału własnego zależy od struktury kapitału, struktury posiadanego majątku oraz przychodów i kosztów z bieżącej działalności (Skowronek-Mielczarek, Leszczyński 2008, s.198). Przedstawiona analiza wskazuje na problemy z uzyskaniem rentowności przychodów, spowolnienie rotacji posiadanego (prawdopodobnie nadmiernego) majątku oraz wysokich kosztów związanych z obsługą kapitału obcego. Mimo niesprzyjających warunków odnotowuje się wciąż dodatni średni wskaźnik zwrotu zainwestowanego kapitału własnego przez badane grupy i organizacje producentów owoców i warzyw z województwa 
kujawsko-pomorskiego. Pozwala to wysunąć wniosek, że przy odpowiednich strategiach zarządzania aktywami oraz kapitałem będą one w przyszłości miały możliwość generowania zasobów pozwalających na ich rozwój, a tym samym zaspokojenie oczekiwań swoich członków. Możliwość zwiększenia dochodów może być decydującym czynnikiem motywującym producentów do zrzeszania się. Jest to istotne, gdyż w Polsce w porównaniu do innych krajów europejskich mamy niski stopień zorganizowania rynku (ok. 20\% przy średniej UE na poziomie ok. 40\%). Organizacja rynku daje możliwość wykorzystania efektów synergii i skali oraz zwiększa konkurencyjność polskich ogrodników na rynku krajowym i międzynarodowym.

\section{Literatura}

Bieniasz, A., Czerwińska-Kayzer, D., Gołaś, Z.(2008). Wykorzystanie modelu Du Ponta do określenia czynników kształtujących rentowność przedsiębiorstw przemysłu przetwórczego, Zeszyty Naukowe SGGW w Warszawie, Ekonomika i Organizacja Gospodarki Żywnościowej 64, 53-64.

Bieniek-Majka, M. (2016). Struktura pomocy finansowej skierowanej do grup producentów owoców i warzyw w Polsce, Roczniki Ekonomiczne Kujawsko-Pomorskiej Szkoły Wyższej w Bydgoszczy 9, 223-233.

Bieniek-Majka, M. (2014). Integracja na rynku owoców i warzyw w Polce jako efekt członkostwa Polski w Unii Europejskiej, Przegląd Zachodniopomorski, Rocznik XXIX (LVIII), 3(2), 81-91.

Czerwińska-Kayzer, D. (2006). Rentowność przedsiębiorstw sektora mięsnego w latach 2002-2004, Roczniki Akademii Rolniczej w Poznaniu - CCCLXXII, 81-90.

Skowronek-Mielczarek, A., Leszczyński, Z. (2008). Analiza działalności i rozwoju przedsiębiorstwa, Polskie Wydawnictwo Ekonomiczne.

Wasilewski, M., Gałecka, A. (2010). Rentowność kapitału własnego gospodarstw rolniczych w zależności od bieżącej płynności finansowej, Zeszyty Naukowe SGGWw Warszawie, Ekonomika i Organizacja Gospodarki Żywnościowej 81, 231-240.

Rozporządzenie Rady (WE) nr 1234/2007 z dnia 22 października 2007 r. ustanawiające wspólną organizację rynków rolnych oraz przepisy szczegółowe dotyczące niektórych produktów rolnych (rozporządzenie o jednolitej wspólnej organizacji rynku) (Dz. U. L 299 z 16.11.2007, str. 1. z późn. zm.).

Rozporządzenie wykonawcze Komisji (UE) nr 543/2011 z dnia 7 czerwca 2011 r. ustanawiające szczegółowe zasady stosowania rozporządzenia Rady (WE) nr 1234/2007 w odniesieniu do sektora owoców i warzyw oraz sektora przetworzonych owoców i warzyw (Dz. Urz. UE L 157 z 15.06.2011, str. 1, z późn. zm.).

Rozporządzenie wykonawcze Komisji (UE) nr 302/2012 z dnia 4 kwietnia 2012 r. zmieniające rozporządzenie wykonawcze (UE) nr 543/2011 ustanawiające szczegółowe zasady stosowania rozporządzenia Rady (WE) nr 1234/2007 w odniesieniu do sektora owoców i warzyw oraz sektora przetworzonych owoców i warzyw (Dz. Urz. UE L 99 z 05.04.2012, str. 21).

http://ksiegowosc.infor.pl/abc/53030,Jak-poglebic-analize-rentownosci-firmy-model-Du-Ponta.html?action=ad\& adid=622440. Data dostępu 10.05.2017. 